\title{
CHALLENGE OF TIME AS A MORAL IMPERATIVE
}

\author{
WENDY DROZENOVÁ
}

\begin{abstract}
The aim of this essay is to consider how the dominant moral theories can be applied to the discourse of disaster situations. In specific times, specific values take priority. Therefore, this article will consider how moral theory deals with time. Kant's moral philosophy has influenced ethics enormously, but rejects the idea of a temporal dimension in ethics; consequently, modern ethics has not devoted sufficient attention to the temporal dimension. Nonetheless, Kantian ethics established the basic principles of respect for human beings as ends in themselves, and for autonomy of rational beings; thus it cannot be ignored. In political decision-making, simply having good intentions does not suffice; they must be accompanied by responsibility. Both the ethics of consequentialism and virtue ethics (the virtue of wisdom) deal with responsibility for the future. Hans Jonas developed a concept of responsibility concerned particularly with the risks associated with new technologies and the ethical requirement to avoid disasters. "Uncertainty may be our permanent fate - which has moral consequences" (Jonas). Public policy should be precautionary. The ethics of disaster preparation planning is distinct from the ethics of disaster response planning.
\end{abstract}

Key words: ethics; time; responsibility; conscience; situation; disaster.

\section{Introduction}

The aim of this paper is to consider whether the dominant moral theories can be applied to the discourse of disaster situations. In order to assess whether or not a theory can provide a plausible answer to critical and unique situations, theories in this essay we shall adopt a sub specie temporis (under the aspect of time) approach rather than sub specie aeternitatis (under the perspective of the eternal) approach. Deontological ethics (from Greek deon, obligation or duty) is concerned with rule following and is not responsive to aspects of time. Nonetheless, they are of enormous significance: found in the outstanding work of Immanuel Kant, this kind of ethics establishes the fundamental principles of respect for human dignity, autonomy, and accepting that a human being is an end in itself (Kant, 1968a).

This paper is not just concerned with what moral philosophy can teach us about disaster ethics but about what disaster ethics can teach us about moral philosophy. We attempt to reassess our thinking on moral principles by looking at disaster ethics. A procedure typically used in disaster ethics is triage and yet from a deontological perspective, it could be considered questionable. Triage is 
The medical screening of patients to determine their priority for treatment, the separation of a large number of casualties, in military or civilian disaster medical care, into three groups: those who cannot be expected to survive even with treatment, those who will recover without treatment, and the priority group of those who need treatment in order to survive (Winslow, 1982, p. 1).

Categorising people in this way may be considered to be ethically unacceptable since medical care should be equally available to all who need it.

Thus what follows from the discourse of disaster ethics is this: At particular times, some moral values take priority. Does this mean that ethical relativism is a necessary consequence? In this discussion, we shall focus on the dimension of time in relation to moral action. Although the majority of philosophers recognize the historicity of moral rules and the historicity of ethical theories, not many have explicitly studied the temporal dimension in relation to moral behaviour.

\section{Time and ethics}

The fact that quite different acts are appropriate in different times had been considered back in ancient times; evidence can be found in the well known passage in the Biblical text of Kohelet (Ecclesiastes) beginning:

For everything there is a season, and a time for every matter under heaven: a time to be born, and a time to die; a time to plant, and a time to pluck up what is planted; a time to kill, and a time to heal; a time to break down, and a time to build up... (Ecclesiastes, 1966, p. 604).

In spite of the evidence provided for this in the existential speech in the book of Kohelet, there is a clear need for any society to have rules regulating human behaviour; and these rules have to be general, not dependent on the moment. Both these aspects, the need for a general law and the awareness of the particularity or uniqueness of the present moment have to be incorporated into adequate theories of ethics, as these contrasting aspects are embodied in praxis. We can suppose that the rules themselves have developed on the basis of long-term experience of particular situations. In our discussion, we shall try to shed light on some of the aspects that should be considered in a discussion on temporality in ethics.

Heather Dyke wonders why the temporal dimension has been neglected in ethical theories:

Ethics seek answers to questions about the moral status of human actions and human lives... Lives have temporal extension, and are experienced from a sequence of temporal perspectives. Thus, one would think that answers to ethical questions should take some account of their temporal features. Yet there has never been a systematic study of the relations between time and ethics (Dyke, 2003, p.1).

In recent years, several works have focused on the intersection between time and ethics. Time and Ethics (Dyke, 2003) is a collection of findings from a conference held at the University of Otago in New Zealand in 2001. The book highlights the various ways these phenomena intersect, such as the issue of personal identity over time, which can make it difficult to hold a person responsible for a deed carried out many years previously; or the 
relevance of the utilitarian criteria of the amount of happiness in a universe in which time is infinite. Several decades earlier, Hans Jonas propounded a temporal perspective of ethics in his concept of responsibility (Jonas, 1984), which is a crucial resource for the ethics of technology and environment. Another resource led to Czech philosopher Jan Sokol's discussion of time: inspired by the work of Paul Ricoeur, he published a book titled Time and Rhythm (Sokol, 1996) in which he gives an overview of the understanding of time in philosophy, traditions, and various sciences. In his later essay "Ethics and Time", he adopted an original temporal perspective on ethics (Sokol, 1998).

Sokol (1998) suggested that temporal features were omitted from modern ethics, probably under the enormous influence of Immanuel Kant. Kant sought to exclude time totally from his concept of ethics, since he considered it to be incompatible with the concept of freedom in his moral philosophy. Sokol points outs that some parts of Kant's Critique of Practical Reason (Kant, 1968b) seem to be more radical than his Critique of Pure Reason (Kant, 1968c) because practical reason (which concerns the sphere of morality) does not acknowledge temporal differences. Existence in time then seems simply to be one way in which a thinking being sensationally imagines the world, and this is reminiscent of the thinking of Plato (Plato, 2001), for whom time, which came into existence simultaneously with cosmos, was just a moving image of eternity (Sokol, 1998).

In his categorical imperative, Kant succeeded in formulating a rule that was completely independent of temporal conditions. In his struggle to save the freedom of human beings, Kant tries to make freedom possible by excluding causality and spatiotemporal constraints from the realm of morality. In fact, Kant identifies free will with practical reason because autonomous will is the faculty to decide to act in accordance with the moral law, and it is the substance of practical reason that establishes this moral law (Kant, 1968a). Moral law is recognized by practical reason, not from experience; while morality concerns the realm of things in themselves, human acts as temporal empirical facts are just phenomena (Erscheinungen) (Kant, 1968a).

Kant eliminated any empirical differences connected with a specific situation through the universal form of the categorical imperative. This ethics, which excludes all that is related to experience, presupposes that the duties of all rational beings are equal and enables us to decide what is good or bad once and for all. According to Jan Sokol (1998), the disadvantage of this kind of ethics lies in the fact that instead of seeking out a moral decision one can instead comply with an (apparent) "obligation", and this is understood to be evident and obvious-yet, in some situations, understanding what "one's duty" may be (in that actual situation) difficult. Besides this, there is no space left for important aspects of moral life, including metanoia, change of mind, and one cannot imagine how actions like penitence or forgiveness could be universalized (Sokol, 1998).

\section{Good will and responsibility}

The questionable nature of an ethics which does not take into account temporal dimensions time seems more obvious in the context of the political sphere. Kant insisted on the a priori character of moral law, and he strictly denied the moral relevance of the consequences of a deed: it is not the outcome achieved by the action that is relevant but the motive behind the 
action; it is only "good will" that matters (Kant, 1968a, p. 393). In contrast to this view, Max Weber, in his famous lecture Politics as a Vocation (Weber, 1964), formulates two different kinds of ethics: an ethics of conviction (Gesinnungsethik) and an ethics of responsibility (Verantwortungsethik), which Weber sees as a necessary quality in politicians (ibid.). The need to take responsibility for the consequences of their actions is especially great among politicians, since they make decisions which may prove good or fatal to a great number of people. Therefore, a politician cannot afford to decide only on the basis of an ethics of conviction or his own good intention. Politicians, according to Weber, must subscribe to the ethics of ultimate ends - that is, responsibility (Weber, 1964). These two kinds of ethicsbased on intentions and responsibility - are complementary, and necessary for a vocation in politics (ibid.).

Dietrich Bonhoeffer (1966) explains the need to take responsibility for the consequences of one's actions and for history - at least, the history of one's nation-in a similar way, but places greater emphasis on the dimensions of responsibility. He criticises the "neo-protestant ethics of good intentions" and attributes the idea of responsibility for history before God to Christian ethics (Bonhoeffer, 1966). According to Bonhoeffer, "good intention" is not sufficient for a truly moral act, as there is always responsibility for success as well: "Wisdom and foolishness are not ethically indifferent, as the neo-protestant ethics of good intentions aimed to teach us" (Bonhoeffer, 1966, pp. 17-18). Bonhoeffer promotes an AristotelianThomistic respect for wisdom, which is one of the cardinal virtues in virtue ethics: Since success is not morally neutral, and neither are foolishness and wisdom (Bonhoeffer, 1966).

Owing to the situation confronting the German nation after Hitler came to power, Bonhoeffer had to find a new way to reflect upon the moral state of society and to deliberate concepts in ethics. He tried to find out why the German nation was obedient to a regime which was clearly immoral. Bonhoeffer was convinced that the cause was not to be found in the lack of bravery and self-sacrifice of the people, but in the belief that obeying the law was the highest moral principle: "We had seen the meaning and the greatness of our lives in the subordination of all our personal wishes and thoughts to the task which was put on us" (ibid., p. 12). For the Germans vocation and freedom were two sides of the same coin; in German thinking, the idea of freedom was propounded passionately from Luther to the philosophy of idealism, but it was a freedom seen in the deliverance from selfishness by working for the whole. These moral qualities were misused and there was a lack of personal courage: it is much easier to solve things by fulfilling a principle than accepting personal responsibility for a specific solution (Bonhoeffer, 1966). Bonhoeffer prioritizes free, responsible acts.

If we compare Kantian ethics with the idea of responsibility in Weber's lecture (Weber, 1964) and especially with Bonhoeffer's thinking on pursuing the right course of action in an extremely arduous situation, there are indications that Kantian ethics may be-in some contexts and situations - blind to the challenge of time. Rationalistic aspiration leads a person to strive for rules that are so apparent and indisputable that they can liberate conscience from uncertainty. But uncertainty, chance and risk cannot be avoided completely in any human action, including morally relevant actions. This does not mean that rules are not useful but that moral life cannot be reduced to them. In some cases, responsibility for others prevents us from providing the information demanded and, in the worst case, encourages us to lie. In his novel Les Misérables Victor Hugo provides a good example of such a situation: only the 
lie of a truthful religious sister who had never before lied in her life can save the lives and happiness of other people. In such a case, following the rule (to avoid being responsible for breaking it) would be just selfish. We cannot expect there to be some kind of pre-established harmony which would guarantee that following the rule would lead to the best result in each case.

The solution in the novel contrasts sharply with Kant's position which has been criticized by Bonhoeffer: Kant insists that it was right to tell the truth, in keeping with the principle of truthfulness, even in a situation where a friend is hiding in his house and the murderer pursuing him comes and asks for him (Kant, 1996). Bonhoeffer considers this conclusion to be absurd; for him the solution is not found in following rules, nor does he see abiding by the law to be a source of the integrity of a moral being, it is found in obeying one's conscience (Bonhoeffer, 1998). For Bohnoeffer conscience begins with and seeks out not the law but living God and the living human person: "A conscience, freed from the law, will not shy away from taking on the guilt of another... A freed conscience... is open to those close to us in their hour of need" (Bonhoeffer, 1998, p. 279).

We may reasonably suppose that Kant's answer would differ if he were in a real situation; especially, if the Gestapo or terrorists were coming-instead of one isolated murderer- and there was no chance of his defending the friend. Kant was simply discussing truth-telling in general and was just thinking about "a case", and was not-in contrast to Bonhoeffer-in "a situation" in which his friends really might be endangered by his truth-telling. Romano Guardini highlights this distinction: While "a case" concerns an example used in moral theory to illustrate a difference in the circumstances which could change what is morally permitted, "a situation" involves me, concerns me and my existence (Guardini, 1931). The conscience always relates to a real "situation" and not an abstract "case" to be speculated upon theoretically. A "situation" is constituted by various, often contradictory, demands and human and material relations. As Guardini states "each situation we find ourselves in is unique. It has never occurred before and it will never occur again. Therefore, what is supposed to occur within it will never have occurred before... And it is this which should be described and creatively elaborated on" (Guardini, 1931, pp. 31-32). In a situation the conscience is directed by previous experience and also develops gradually over time.

From this embodiment in time, it follows that norms and principles always relate-in real life - to a particular situation, and to insist that they should be applied in a particular way may lead to absurd results. Therefore, the manner of application must be left to the conscience of the moral agent. On the other hand, the principles cannot be inferred from the situation itself. The idea of "situational ethics" as propagated by Joseph Fletcher (1966) seems attractive, but the principle of "love" (agape or caritas) on which it is based is too vague to serve as a criterion of ethics. J. Lédl in Nothing but Love? Optio Fundamentalis as a Criterion in the Situation Ethics attempts to substitute the vague moral criterion (presented by Fletcher) with the concept of "fundamental decision", and explains that in real life the quality of a moral decision depends on the moral level of the moral agent (Lédl, 2009). Here, Lédl's position seems to come close to that found in virtue ethics which holds the well-developed notion that there are stages of virtues that a moral agent can attain. Virtue ethics includes temporal dimensions: In the different stages of maturation an individual (communities or nations) attains we can expect and demand different levels of virtues. Virtue ethics, which allocates 
the central position to wisdom (Aristotle, 2013), comes close to the concept of responsibility. When their capacity for wisdom is improved, the individual can make better decisions, foresee the consequences of a specific act or inactivity and take responsibility.

From what has been said, it is clear that in difficult situations personal responsibility can be expected only from a person who has attained a high moral level. But the personal moral condition is not a constant; it is a dynamic factor depending on personal effort and knowledge.

\section{Challenge of time as a moral imperative}

Undoubtedly, Kant's moral philosophy constitutes one the most influential conceptions of ethics in the modern times. Kant's respect for human dignity, the human being as an end in itself, means that no human being can be used as a means for any other end (Kant, 1968b), and this is always significant. Besides being important in philosophy, it is vital to other disciplines that rely on a concept of the human being and his/her autonomy, especially politics, and in medical ethics and bioethics, in relation to protecting the right of a person-or a patient- to make decisions about themselves. The most influential book in bioethics, Principles of Biomedical Ethics (Beauchamp \& Childress, 2009), postulates that the principle of autonomy is one of four key principles, and makes explicit reference to Kant in many contexts.

This categorical imperative cannot be denied, even where the dimension of time is incorporated into the ethical discourse, and it is also valid in the disaster ethics. Hans Jonas in his Imperative of Responsibility adds a time horizon to the moral calculus present in Kantian ethics (Jonas, 1984). In his "Old and new imperatives" chapter, Jonas explains that Kant's categorical imperative "was addressed to the individual, and its criterion was instantaneous" (ibid., p. 12), while his own "ethic of the future" takes account of real consequences.

Jonas had to distinguish his attempt at formulating a new ethics from earlier forms of "future-oriented ethics" (p. 12), in particular from modern utopia and from the ethics of fulfilment in the life hereafter. The latter, he explains, concerns a life that is good in itself (including virtues, like justice, charity, purity of heart etc.) and that is supposed to be awarded in future life, and, therefore, this preferable way of life is the best option in any case, even if there is no hereafter. Thus, the presence characteristic of ethics is preserved in this case (Jonas, 1984). The relation between modern utopia (represented notably by Marxism) and ethics is different. The modern idea of progress made possible the emergence of a secular form of chiliasm, in which everything preceding the coming ideal society is understood just as a preliminary stage of it. Therefore, the ethics of the present time has only a preliminary character, while the real ethics of the future (in the coming society) is not yet clear and actual: the ethics in the preliminary stage need not do justice to human nature, as events occurring in the present time are understood just as a means for the future (Jonas, 1984).

In his thoroughgoing analysis, Jonas explains the difference between the stance explained above and his ethics of responsibility for the future, which is authentic and does justice to the demands of today-that is, following moral rules (including Kant's categorical imperative) and aiming to fulfil the meaning of life of the individual in the present time. Therefore, 
Jonas attempts to formulate an ethics which is neither chiliastic nor utopian. Faced with the threats brought by technology, including the threat of nuclear war, ecological destruction, and genetic engineering, Jonas takes seriously the moral obligation to be aware of the altered nature of human action: it may result in total destruction. In contrast to earlier forms of ethics that took into account only the rules of behaviour and one person's responsibilities to another (that is, relations between existing people), it is now necessary to extend the scope of morality to include nature, and to future generations.

The objective of Jonas' work was to develop an ethical theory adequate for an era of modern technology that possesses the ability to cause long term damage to nature or even make future human life impossible. While Das Prinzip Verantwortung is an attempt to provide the general basis of the concept of responsibility in ethics, Jonas's later work Technik, Medizin und Ethik: Zur Praxis des Prinzips Verantwortung is "the applied part" of the former, and gives a more detailed elaboration of his ethics of technology (Šimek, 2014, p. 51). In it, Jonas warns against new medical technologies, especially genetic manipulations, which may make it possible to deliberately shape future generations, and disrupt the successful process of evolution (Jonas, 1987, p. 174). Today, the new possibilities of human enhancement have led to the emergence of the concepts of transhumanism and posthumanism, and urgent questions about the moral limits of medicine: Should human nature be changed? Should we (ir)reversibly change the anatomy, physiology or genes of individuals or society as a whole? Contemporary medicine has to take future generations into consideration (Payne, 2015).

Because of the threat associated with the vulnerability of nature and the lack of power over technology, Jonas is convinced that human survival depends on purposeful efforts to care for our planet and its future. Given the nature of modern technology combined with science and the fact that is has spread all over the world, the moral philosophy of our time has to extend the previous area of responsibility. Jonas summed up the challenge of the time in a new moral imperative: "Act so that the effects of your action are compatible with the permanence of genuine human life", or in other words: "Do not compromise the conditions for an indefinite continuation of humanity on earth" (Jonas, 1984, p. 11). Jonas's concept of responsibility provides us with a way of avoiding ethical relativism, without neglecting the challenge of the time

There is always an element of wager present in human action. If all the interests of humankind were at stake, Jonas suggests that a bad prognosis would prevail over a good one: "the heuristic of fear" (Jonas, 1984, p. 26) can help us to avoid the most evil disasters. Jonas's attempt to formulate an ethics adequate to the time led him to a widely accepted precautionary principle. In questions of disaster ethics, the precautionary principle could prevent man-made catastrophes. From the precautionary principle, it follows that there is a social responsibility to protect the public from exposure to harm, and the onus is on those performing the action to provide proof that the new technology or process is not harmful (Wingspread Conference on the Precautionary Principle, 1998).

The heuristic of fear teaches us that a bad prognosis should have priority over a good one.

As long as the danger is unknown, we do not know what to preserve and why. Knowledge of this comes, against all logic and method, from the perception what to avoid. This is perceived 
first and teaches us, by revulsion of feeling which acts ahead of knowledge, to apprehend the value whose antithesis so affects us. We know the thing at stake only when we know that it is at stake (Jonas, 1984, p. 27).

"Uncertainty may be our permanent fate - which has moral consequences" (Jonas, 1984, p. 191). The moral consequences especially concern politicians, since they have the power to put the interests of others at stake, and therefore, they are responsible for them (Jonas, 1984).

\section{Conclusion}

In this essay, we have tried to link some substantial ethical principles with aspects of time, so as to view moral philosophies sub specie temporis. From the perspective of the discourse of disaster ethics, it seems clear that we can expect only a theory to provide a plausible answer to real problems which is sensitive to time and its challenges and can take into account responsibility for the future. Generally, the aspects of time are included in any theory that considers consequences. The virtue of wisdom, promoted by Aristotelian-Thomistic ethics, includes foreseeing the outcomes of a decision and the ability to make a good or the best choice; this ability can be improved over time. The idea of consequence presupposes causality: the effect is ascribed to the action, whether the agent intended the result or not. This may be confusing, as the agent need not necessarily have intended the result. Vasil Gluchman (2008), a proponent of the ethics of social consequences, a form of non-utilitarian consequentialism, has successfully elaborated a theory of morally right and wrong acts that accords with moral intuition: in short, we can judge whether an action was right or wrong by its outcomes, but the motives for it (not always clear in real life) may have been morally bad (if bad intentions were to prevail over good ones) or morally good (the opposite case), and the quality of the intentions comes into the quality of the act, in which they issued. A moral act is both objective and subjective and in this respect is time related and dependent on knowledge and the moral level attained by the individual (Gluchman, 2008).

The imperative of responsibility projected by Jonas highlights the changed nature of human action resulting from modern technology. Jonas assigns public policy the principal role:

If the realm of making has invaded the space of essential action, then morality must invade the realm of making, from which it has formerly stayed aloof, and must do so in the form of public policy. Public policy has never had to deal before with issues of such lengths of anticipation (Jonas, 1984, p. 9).

What consequences follow for disaster ethics? The obvious conclusion is to use predictive science to anticipate future risks and to choose how technology and society can develop in a way which is not determined just by short-time profit but prioritizes alternatives which are compatible with long-term safety and sustainability. Therefore, obtaining responsible power over the processes becomes a crucial task, and decisions concerning the future orientation of technologies should not be beyond democratic control.

Having an awareness of the uncertainty of prognosis means that disasters which have not been predicted can be foreseen: 
The known fact of contingencies, in the absence of knowledge of precisely what those contingencies will be, entails that disaster preparation is not the same thing as disaster rehearsal. No matter how many mock disasters are staged according to prior plans, the real disaster will never mirror any one of them (Zack, 2009, p. 58).

The question is how can we distinguish between an ethics of disaster preparation planning and an ethics of disaster response planning (Zack, 2009)? Disaster preparations must be sufficiently general so the plans can be adapted to the situation in hand. Other questions may present themselves, such as how resources should be allocated: "Do we, for example, choose more health care for normal times or more supplies for a possible pandemic? In a democracy, the answer to this question needs to be decided by open discussion and public opinion" (Zack, 2009, p. 66).

Disaster ethics involves practical-political questions and the ethics of politicians. The ethics of politicians should be guided by responsibility, and disaster avoidance is an integral part of this responsibility. It includes prioritizing a bad prognosis over a good one. "Uncertainty may be our permanent fate - which has moral consequences" (Jonas, 1984, p. 191).

\section{Acknowledgement}

Funding for the workshop on moral theories and disasters at the University of Prešov, Slovakia (13-15 May 2015) and open-access publication was provided by COST Action IS1201 (http://DisasterBioethics.eu).

\section{References}

Aristotle (2013). Nicomachean Ethics. London: W. Heinemann; Cambridge, Mass.: Harvard University Press.

Beauchamp, T. L., \& Childress, J. F. (2009). Principles of biomedical ethics. New York: Oxford University Press.

Bonhoeffer, D. (1966). Nach zehn Jahren. [Ten years later]. In Widerstand und Ergebung (pp. 9-25). München \& Hamburg: Siebenstern Verlag.

Bonhoeffer, D. (1998). Ethik. [Ethics]. Gütersloh: Kaiser.

Dyke, H. (2003). Introduction. In H. Dyke (Ed.), Time and ethics: Essays at the intersection (pp.1-7). Dordrecht: Kluwer Academic Publishers.

Ecclesiastes (1966). In The Holy Bible. Revised standard version (pp. 603-609). London: Catholic Truth Society.

Fletcher, J. (1966). Situation ethics: The new morality. Philadelphia: The Westminster Press.

Gluchman, V. (2008). Etika a reflexie morálky. [Ethics and reflections of morality]. Prešov: Filozofická fakulta Prešovskej univerzity.

Guardini, R. (1931). Das Gute, das Gewissen und die Sammlung. [The good, conscience and concentration]. Mainz: Matthias-Grünewald-Verlag.

Jonas, H. (1984). The imperative of responsibility: In search of an ethics for the technological age. Chicago \& London: University of Chicago Press.

Jonas, H. (1987). Technik, Medizin und Ethik. Praxis der Prinzips Verantwortung. Frankfurt am Main: Suhrkamp. 
Kant, I. (1968a). Grundlegung zur Metaphysik der Sitten. [Groundwork of metaphysics of morals] (pp. 385-463). In Kants Werke: Band IV. Berlin: Walter de Gruyter.

Kant, I. (1968b). Kritik der praktischen Vernunft. [Critique of practical reason]. In Kants Werke: Band V. (pp. 1-163). Berlin: Walter de Gruyter,

Kant, I. (1968c). Kritik der reinen Vernunft. [Critique of pure reason]. In Kants Werke: Band IV. (pp. 1-252). Berlin: Walter de Gruyter.

Kant, I. (1996). On a supposed right to lie from philanthropy. In M. J. Gregor (Ed.), Immanuel Kant, practical philosophy (pp. 611-615). Cambridge \& New York: Cambridge University Press.

Lédl, J. (2009). Nic než láska? Optio Fundamentalis jako kritérium v situační etice. [Nothing but love? Optio Fundamentalis as a criterion in situation ethics]. Praha: Unpublished MA dissertation. ETF UK.

Payne, J. (2015). Předmluva [Introduction]. In J. Payne, A. Doležal, D. Černý, et al. Dobrý, nebo lepší život? Human enhancement (pp. 5-12). Praha: Ústav státu a práva AV ČR.

Plato (2001). Timaeus. Newburyport MA: Focus Publishing R. Pullins Company.

Sokol, J. (1996). Čas a rytmus. [Time and rhythm]. Praha: Oikúmené.

Sokol, J. (1998). Etika a čas. [Ethics and time]. In Čas a etika: texty k problemu temporality. [Time and ethics: Texts on the problem of temporality] (pp. 9-28). Praha: Sofis.

Šimek, V. (2014). Etika techniky podle Hanse Jonase. [Ethics of technology according to Hans Jonas]. Filosofie dnes, 6(1), 50-83.

Weber, M. (1964). Politik als Beruf. [Politics as a vocation]. Berlin: Duncker \& Humblot.

Wingspread Conference on the Precautionary Principle (1998, January26). In Science and Environmental Health. Retrieved from http://www.sehn.org/wing.html

Winslow, G. R. (1982). Triage and justice. Berkeley: University of California Press.

Zack, N. (2009). The ethics of disaster planning: Preparation vs response. Philosophy of Management, $8(2), 55-66$.

Institute of Philosophy,

Czech Academy of Sciences,

Jilská 1,

11000 Prague 1,

Czech Republic

E-mail: wendy.drozenova@ seznam.cz 